\title{
UNDERSTANDING EDUCATION IS THE ACQUISITION OF A PROFESSION (OR PROBLEMS OF WORLDVIEW CHANGE)
}

\section{Qayum Shayimovich Baymirov}

Candidate Of Pedagogical Sciences, Head Of The Department, Institute Of Retraining And Advanced Training Of Directors And Specialists Of Preschool Education Organizations, Uzbekistan

\section{ABSTRACT}

The importance of targeted and meaningful tools for the formation of worldviews. The importance of philosophical views in today's world. The logical increase of personal responsibility in the educational process. Theoretical-scientific, practical efforts have been made to substantiate the fact that external influences play an important and stable role in the formation of the individual and the acquisition of a profession.

KEYWORDS: - Textbooks, first step, philosophy, pedagogy, school, profession, cinema, thinking.

\section{INTRODUCTION}

The main means of determining the socioeconomic and political development of the country are tolerant, logically-minded, courageous citizens with material wealth and a perfect outlook. Therefore, the material interests, spirituality, enlightenment, culture of the nation are measured and glorified by a logical book literature (teaching materials). It is true that the historical process in human society is evaluated by historical sources - written manuscripts or books (textbooks and sources) written by our ancestors and left a worthy contribution to world civilization. Indeed, states around the world will never stop innovating and researching to make reforms in their own interest. This law applies to the science of philosophy, where the struggle and unity of opposites, the denial, the change of quality leads to the change of quantity. In simple and straightforward terms, the existing space of nature is closely and continuously connected with the development of time. Which is an essentially inseparable process for an individual's worldview, where form and content are mutually equally powerful and have a range of influence.

Note, a living philosophical example. In the course of a lesson to a philosopher, his listeners brought him a very ugly form and asked him: is there any content in this form? Then the philosopher thought seriously and said, "I will 
CURRENT RESEARCH JOURNAL OF PEDAGOGICS 2(12): 44-48, December

2021 DOI: https://doi.org/10.37547/pedagogics-crjp-02-12-10

ISSN 2767-3278

(C)2021 Master Journals

Crossref do: 81 Google

Accepted 10 $10^{\text {th }}$ December, 2021 \& Published $15^{\text {th }}$ December, 2021

discuss this topical issue with the professors of the department and I will give my conclusion later. In this regard, the professors of the department, with a simple look, based their conclusions on this and said that the form has no content. However, no one paid attention to the conclusion of one of the philosophers of the department that "this form is the essence." In our opinion, it would be expedient for the reader to understand that the roots of the sciences of "philosophy" and "philology" in expressing the content with form and clarifying it are the same, the basis of their views is "wisdom".

\section{Reform starting with the "first step"}

The state program "First Step" sets important requirements and rules for students attending preschool education. A child brought up in this type of education faces various difficulties and seemingly insignificant daily problems in mastering the state program. Of course, even seemingly insignificant problems must be solved by educators with a clear and beautiful understanding, creative research and a broad outlook. It is very important to realize that we are in the realm of miracles, based on a single scientific conclusion, not on the aspirations of the educator, but on the whims or masculinity of the educator and in a positive way. We cannot forget the important natural process. Today, let us expand the value of our ideas, radically change our worldview. The main thing is to quickly forget the rule of living from someone, and turn our first and foremost aspirations on all fronts into positive confident steps.

Let us be perfect and deep in understanding the essence of the philosophical and philological "form and content." Why do we express different opinions without genuinely scientific understanding of changes in society or the state, but it is still the same old and easy way of acting: seeing someone, being "smart", we can not get rid of our shortcomings. I would like to express to you my hesitant or skeptical views on selfawareness and my various thoughts on various actions with a "complaint", simply a small "claim".

\section{Philosophical philological thoughts}

In the renewed reforms on the way to a new Uzbekistan, the claim that I have found myself in a radically new form and content is, have I chosen the right profession? As time goes on, I find it difficult to understand the form and content of this claim. In particular, being "quick to recognize" or "smart" to managers makes it harder for me to evaluate myself as I watch or hear new "names" and appearances that are hidden in my "underlying" and "deep" personal interests, and even more painful, various questions arise. Understanding, shallow and deep, everyone has their own worldview and corresponding and inherent inseparable consequences. Worldviews and the formation of this state in the individual are constantly carried out at the expense of biological development, in which the environment and mastered beliefs are closely related to the stage of cognition and youth, developing philosophically different forms and content. It also builds a beautiful patterned attractive daily activity by shaping the texts in the philological statement in person. Often it does this without realizing it. Here's another non-serious look! I am writing this. But the criterion that cautious people have considered is whether this person (I) has a moral or official right or whether he or she should not dedicate so many pages to an article he or she has written. As far as the precious power is concerned, I have been following a truth with philosophical rules from a philosophical point of view. No one who has written anything can completely surpass his intellect. It should be noted here that the same human rule applies to reading and writing or analyzing sources. Because the practice of knowledge (consciousness) must be firm in our dream intentions. For humanity, the means of 
CURRENT RESEARCH JOURNAL OF PEDAGOGICS 2(12): 44-48, December

2021 DOI: https://doi.org/10.37547/pedagogics-crjp-02-12-10

ISSN 2767-3278

(C)2021 Master Journals

Crossref do: 81 Google

Accepted 10 $10^{\text {th }}$ December, 2021 \& Published $15^{\text {th }}$ December, 2021

literature (understanding and morality) that are philosophically meaningful and shaped by philological influences - books are very tasty and sweet when written and read. Unfortunately, to say that I teach all the books written by people in today's human society is a much more difficult task than to be a criterion for evaluation (practice) expressed in terms of quality or numbers in the formation of worldview. The main tool that influences the formation of personality - books are loved and read, which gives spiritual strength to our consciousness, and the reader is engaged only in books - literature, because it is very difficult to find this form of information communication - perfect (!) technique. I have heard from a person through the media that finding the logically perfect answer to the question "why did I come, what am I doing" was recommended to be understood through the science of psychology. We believe that finding answers to these questions would be appropriate if it is a matter and problem of philosophical philological thought.

\section{The meaning of essence in form and content}

I always think seriously about a situation that is continuous and responsible, especially when I talk to someone who is writing "something" or "a very important issue for him - a socio-economic, political issue" or hear his point of view, I begin to re-evaluate myself; "Did I choose the right profession?" Again I observe the surroundings in peace and quiet without melting, I see the essence of the demand for useless form and content. Again, my thoughts go back to that youth, the Indian cinema that brought Ghani to the village as a "filmmaker" and its protagonists. But I always set goals straightforward that I have to change for some reason. The transformation of the world for the benefit of man is inextricably linked and consistent with form and content in changing the worldview.

We used to watch a lot of Indian movies when we were students, movie heroes often interacted with a slanderer or a slanderer, and what seemed to be positive quickly created a problematic situation, the "hero" we were watching, the poor man unknowingly interfering with something or simple communication and he would slowly get into something interesting, thinking that he would achieve something. Unfortunately, such aspirations caused many problems in daily life. In the end, there would be mostly positive solutions. There are a lot of movies like "Elephants are my friend", "Flower and stone", "Bobby", "Zita and Gita".

The main part of the chaotic thoughts of our youth were Indian films, while the directions of study were "October", "pioneer", "Komsomol" and finally "party", which were "political" ideas. All the same thinking, the common motto of action "one for all, one for all" hung on the ground. We, namely, the notion of going to the city in the dream of getting rid of the countryside as soon as possible, before the forced labor performed in the same form and content, were a priority or a rebellion.

Let us pay attention to the seemingly simple idea that the New Uzbekistan begins with school thresholds and education, while calmly looking around us, realizing the form and content. After all, these calls and reforms are being put forward for the prosperity and future of the Nation and the Motherland. We are often preoccupied with superficial discussion or critical thinking without understanding the form and content of ideas. We must clearly and unequivocally understand that these calls and reforms stem from the conclusions of our recent history. That is why it is important that we take a responsible approach to the terms "kindergarten", "school", "education", "threshold". We have no right to hesitate - these terms are the future of the Nation and the Homeland.

I have read that school is a place of rest, so school 
CURRENT RESEARCH JOURNAL OF PEDAGOGICS 2(12): 44-48, December

2021 DOI: https://doi.org/10.37547/pedagogics-crjp-02-12-10

ISSN 2767-3278

(C)2021 Master Journals

Crossref doi) 81 Google

Accepted 10 $10^{\text {th }}$ December, 2021 \& Published $15^{\text {th }}$ December, 2021

is a place of rest for the search and selection of books and professions, a place of care - a place of miracles! Again, that simple and straightforward question: Did I choose the right profession? Well, let one of my peers say I chose the right profession. But I don't believe it because he's also seen Indian movies, maybe he's a fan of those movies. So I do not believe that he chose the right profession or practical activity. Justice is often spoken by the unjust without thinking. Which, again, starts to say small things, write, or put on a movie-youtube. In my observations, I often witness these qualities, mainly those who are unjust in themselves, seek justice.

The effects of all the laws of science that are being taught and studied in the human society of the world, the development of natural or social sciences, begin to occur, first of all, in ourselves. There is no such thing as perceiving or realizing this. It is the essence of a perfect philosophical philological form and content. Therefore, the search for the understanding of this situation, and the search for it again, is the fact that the conclusion is a continuous and continuous inseparable phenomenon. Therefore, from the "first step", the person (child) must first fit himself. Therefore, the conditions must be consciously prepared for it to find its own response to its whims as much as possible. Things that seem simple can eventually lead to bigger awareness or, conversely, bigger results. We are often suddenly overwhelmed by society, socio-economic environment or political processes.

Again the same question: did I choose the right profession?

When a person reads a book (textbook) and then strives to become a professional, many things become clearer and more transparent. Let us not be mistaken, divine or practical messages to humanity have come from the most basic medium - books (literature) - in harmony with nature. On the basis of the book (literature), it was enough for humanity to look for solutions to all problems later. Research has led to the search for knowledge, not slander or libel.

\section{Then in place of the word (or conclusions to come)}

I walk in many cases saying that he who knows everything knows nothing, he who knows one thing knows everything. Also, all the existing branches of science in the world have a constant and moderate effect on the human mind and consciousness at the same time. There is a need for a deep understanding and a peaceful torment (soul) in order to seize this opportunity from a person with the help of the intellect.

After all, if you go too deep to understand an issue, you will eventually have to do it yourself and again. If you don't believe, try to understand yourself without melting again and wait for the result, the result will be you and yourself forever. Because if you come to the fact that there is no sign that the same person is above and below the earth and there is not, then, of course, gratitude can be embodied in the heart and mind. With a clear mindset, delve into the essence of the chosen issue and try to be objective, confidently go to the school of miracles - the threshold of the educational space. Then, looking at the socioeconomic changes in our country, the practical work seems to be very easy. But the effectiveness of the results in our country does not happen by itself, there is pain and ingenuity to understand it, it is to understand the literature, to acquire a profession.

I always have some or all of a different perspective on my career. Let's pay high and clear attention to the science of philosophical philology (literature) "science" - mathematics. Then whoever we are, we have to draw our own conclusions for ourselves. It's so easy to live with someone. This is the root cause of dependency and poverty. The product of any human etiquette 
CURRENT RESEARCH JOURNAL OF PEDAGOGICS 2(12): 44-48, December

2021 DOI: https://doi.org/10.37547/pedagogics-crjp-02-12-10

ISSN 2767-3278

(C)2021 Master Journals

Crossref do: 81 Google

Accepted 10 ${ }^{\text {th }}$ December, $2021 \&$ Published 15 th December, 2021

begins with the logical admonition not to give free rein to the "tongue" in the first place in education. Because there is no need to hide, a person earns his reputation through constant research. A person must always be able to apply this truth in an equal way to everyone, first and foremost. The economy of independence becomes a problem in creative thinking and will have its own solution. But again, I wonder, did I choose the right profession? I regularly watch other people on this issue, I see useless forms, again that Indian cinema and its protagonists ... but change is necessary. The same question again: did I choose the right profession? Socioeconomic reforms in our country are moving from kindergarten to school politically, and then it will become clear that this issue will be addressed in relation to other types of education. I have a lot of distrust of today's "heroes" in a critical or protest mood. The main reason is again that career choice and Indian movies come to mind. Once again, please calmly and patiently read the books (textbooks) that your grandson is reading. Who is the book written for, does it have the spirit of your grandson or is it a teacherteacher degree?

Think a little calmly! Are you satisfied with what you do, first and foremost? In short, do you need it? Or do you take the spiritual nourishment for your past life, build a jilla, ask yourself the question, did you choose the right profession? Is there any scientific basis or legal recommendation as evidence for this? Have you mastered the profession correctly or is the choice of profession difficult? ... these are the questions I have. The answer is Indian movies.

\section{REFERENCES}

1. Spirituality is the cradle of destiny. Risola / Baymirov Q.Sh. -Tashkent: Publishing house "Fan" of the Academy of Sciences of the Republic of Uzbekistan, 1996. - 24 p.
2. Continuing education: career choice and confidence. Textbook / Baymirov Q.Sh. Tashkent: "Tafakkur" publishing house, 2014. - 136 p.

3. Science and education: harmonization, problems, solutions. Monograph / Baymirov K.Sh. - Tashkent: National Society of Philosophers of Uzbekistan Publishing House, 2020. - 176 p. 